\title{
The Portrait of Democracy and Local Culture in the Land of Kings: Recruitment Study of Elite, Natural Resources Management, Social Community, Conflict, and the Conservation of Local Culture of Hila
}

\author{
A Lating \\ \{alilating@yahoo.com\} \\ Lecturer on a Course of Government Study, Social and Political Sciences Faculty. \\ Muhammadiyah University of North Maluku, Indonesia ${ }^{1}$
}

\begin{abstract}
The development democracy at the local level can be seen not only from the process of reproducing new elites and playing the important role in local politics but also from the role of local culture as a media to organize the work of local democracy. Democracy and local culture are strongly influenced by the norms and values that form the basis of the operation of democracy and culture process, values and norms that have been born together with the presence of community. As a community that already has the structure and system, either good governance or good community, those values and norms have become "The Best Way of Life' and guidance of action to manage the power relationship between people, nature, and institutional structure that has been formed, as well as a capital to survive. This article is a small portrait of democracy and local culture on the aspects of elite recruitment (king), natural resource management, social community, conflict management and cultural preservation of local culture of Hila, which is important to know in order to understand the dynamics and complexity of Indonesia. By understanding the diversity of democracy and local cultures, we can improve those points base on the context and culture at the local level.
\end{abstract}

Keywords: Democracy, Local Culture, Elite Recruitment

\section{Introduction}

Consciously or unconsciously humans always nurture, foster and develop relationships between humans. In the framework of such efforts, humans reside together - a place that can meet the needs of his life. Elements of circumstances and environments affect where a commonplace of residence is held. On the beach, deep into the hinterland, on the slopes, and on the mountain even on the water. From the perspective of psychology, human beings have some natural impulses, including the so-called social theorist, the impetus of segregation (separating) and the impulse of integration (submission). The social drive encourages people to always live with other people in a group. The encouragement of segregation encourages human beings to form groups based on the same or common traits and interests, the goal of segregation ultimately gives birth to a group that possesses various functions and controls 
certain aspects of people's lives. The impetus for integration is the individual or group encouraged to submit, obey and seek refuge in a person or a whole group. These three impulses resulted in the formation of a social institution, which at the beginning of the primitive human life, is very simple. The formation of social institutions is accompanied by the presence of a person or a few people who lead, which gradually evolved into a government agency equipped with the power to maintain an orderly life.

Based on the impulse of nature above the person or group that is a lead is sincerely obeyed by all that is laid, pure obedience and mutual trust. Life together to build a house in a small group not only exist in Indonesia but also in other countries at the beginning[1]. This community/group is labeled Kampung (West Java), Negorij (Maluku), Wanua (Makassar). This group also has a culture that governs relationships between freedom and the environment[2]. The development of state administration in Indonesian society was present before the arrival of the Europeans. There are government institutions that basically have three levels, first national, second-level district, and third-level Village. Burger's research results confirm the life of the people of Java in antiquity can be distinguished four stages of the king's first king, the two local leaders and the three heads of Village and the fourth mass or community Village[3]. The group also has a culture that governs relationships between independence and with its environment. The development of state administration in Indonesian society was present before the arrival of the Europeans. There are institutions of government which are basically three levels, first national, second-level district and third level Village.

Living together creates a living order that evolves into adat, which is adhered to unconditionally by all members of society. Adat is nothing but an unwritten law, from generation to generation since the ancestors of the law to the breaking of the action of the whole group. Each region in Indonesia has customs that govern and manage life together. The arrangement of the collective life arrangements covers the various aspects of life both aspects of government management (recruitment of kings as well as customary/cultural duties and functions), direct election of kings is a process of deepening democracy[4], [5] (deepening democracy) for the community, where the community is involved in continuously administering or in government (king) elected for the next period. Even if viewed from procedural sperspektif, result leader through a democratic election mechanism. It takes place freely, honestly, fairly and minimally violence. Natural resource management based on local culture, aims to ensure the sustainability of production and better outcomes, social management to ensure comfort and order, conflict management, problem-solving by prioritizing the genealogical aspects of the sustainability of kinship and cultural to ensure the existence of value order and harmonization among others.

\section{Method}

This research focuses on field research, therefore this research includes descriptive research that is; research by describing and describing a series of events, phenomena or facts relating to problems and research units in the field. The research results are emphasized on providing an objective picture of the true state of the object under investigation[5]. The date to described in this research is how the democratic process and local culture in the recruitment of local elites (king), natural resource management, conflict management, and cultural preservation. conversation and the range of actions performed and supported by some documents and photos. Date collection procedure in the form of the main date and supporting date. The main date is obtained from key informants such as traditional figures and public 
figures who understand the local culture and the meaning contained in the culture. Instrument data collection in qualitative By using qualitative research methods indirectly researchers must go to the field to study the object of research studied in order to obtain the necessary data. The main data source in this research is the result of the (a) Observation Technique, interpreted as a systematic observation and recording of the phenomenon of the phenomenon being investigated[6], (b) Documentation Technique, data collection technique defined as a written report of an event consisting of explanations and estimates of events, and written intentionally for store or forward information about the event. (c) .Technique interview, to know what is contained in the mind and heart of others, how the view of the world, that is things we can not know. The same definition is also explained more technically and broadly[7] by Moleong[8]. Conversation with a specific intention, a conversation conducted by two people I interviewer (interviewer) who asked questions and who interviewed (interviewed) which provides answers to questions. Three important approaches to be considered by an interviewer namely; Informal interviews, approaches using general guidelines for interviews and open standard interviews. Analysis date techniques include: date reduction, display and conclusion / ferivication

\section{Theoretical Perspective}

\subsection{Democracy}

There are two approaches commonly used by experts when explaining the concept of democracy. That is the normative classical approach which is also known as the substantive approach and the minimalist empirical or procedural approach. The normative classical view, democracy is understood as the source of authority and purpose, while the minimalist empirical approach emphasizes the built-in political system (the growing democratic construction of space and time). The normative classical approach is more dominant in explaining the ideas and ideology of democracy substantively and generally defining democracy by the terms of the will of the people as a source of tools for achieving the common good. The minimalist empirical approach becomes the entrance in explaining democratic modeling. First, it is a perspective that refers to a political form where direct community involvement in government processes and policy reproduction (policy/rules). Second, the perspective that refers to how the mechanism of the decision-making process is implemented. Second, the perspective that refers to how the mechanism of the decisionmaking process is implemented. The meaning of democracy is based more on the basis of a government that comes from the people, by the people and for the people rather than others. [9]

Robert A Dahl at least there are a number of impacts as a result of democracy, among others; avoiding tyranny of power, expressing human rights, public freedoms, selfdetermination, moral autonomy (individuals can express what autonomously wants), political equality[10] democracy of at least three requirements must be fulfilled which is the first individual in the society voter age adults) should be entitled to the right to determine their leader to derive from the principle of equal rights in democracy itself whose locus is on free and autonomous individuals. Second, effective participation, within the whole process of collective decision-making, the stage of determining the work agenda. Third, the Disclosure of Truth: At a predetermined time, for the necessity of a decision, every citizen must have the opportunity and sufficient to make logical judgments in order to achieve the most desirable outcome. Fourth: The last control on the agenda: the public must have the exclusive power to determine the issues. which matter should and should not be decided through a process that 
meets the criteria of democratic criteria. Fifth Coverage: The public should include all adults in relation to the law except for temporary migrants[11].

\subsection{Local Culture}

Local culture for local people is not merely a reality but is fundamentally a fact of existence that shapes the history, culture, charm of personality and identity of his community. Local culture, therefore, should be read in the eyes of culture to explore all the ins and outs and dynamics or strategies - the community strategy to deal with and build a civilized life (Habitual). For local communities, the composition, thoughts, content of appreciation or composition of local cultural values referred to our special. The reason, because it contains ethical values, spiritual and moral order, and the hidden ratio with validity and validity in the customary order. Local culture for its people, in essence, has very ideal and operative values. Ideally, because the local culture of the local community is The Best way of life or life view, which serves to guide and direct and control the private life and togetherness in a collective collegial indigenous Community. One of the regulative functions of local culture is to strengthen the unity and integrity of indigenous people's life, to maintain the survival of generations, to conduct social order (social order), every government and order of leadership, order of nature (natural order) which all focus on one purpose ie growth and development of indigenous people's in a stable existence order. Affirmative function, to discipline life and affirm the public image in the customary order Local culture has a value meaning that at the same time can arrange governance management. Local cultural values in the view of Prof Watloly include: (a). Developing Elegant Traditions In Decision Making: (b) Trusts between Communities and Governments: (c) No Accumulation of Wealth nor Powers for Personal Interests: (d) Become a Leader To Strengthen Fraternal Relationships: To be a leader is a means of creating an essential fraternal space between fellow. While operative (technical operational) as a guide action to direct the performance of the joint as a culture of life in building prosperity, happiness, and peace of life together with other human beings as well as others. Everything to continue circulation of sustainability/sustainability in order to stay awake and productive from generation to generation[12].

Various forms of local culture that lies in the archipelago shown in various customary entities. In the study of local politics in the form of the local culture can be traced in 3 domains, namely: First the realm of power related to the recruitment of local leaders, government management. Second. Environmental Management and Third Conflict Management Tradition of government management by promoting local values are found in various regions of Indonesia[13].

\section{Result and Discussion}

\subsection{Art History}

The elit recruitment traditions, both related to the strategic elite within the governmental environment (Raja, Upu Hata, Soa Chief, etc.) as well as religious leaders have strong historical roots and begins with the presence of four prime. The presence of these four premiers also laid the foundations of governance that prevailed to this day. The early presence of the four primates lying on a hill called Paunusa or Uli Halawang hill provides a natural alliance as well that the life order of the group of people of this period has now earned the title of "Uli Halawang" Community. In addition to Uli Halawang country, there are three other countries namely Massapal, Sanalu, and Wawane. In the structure and governance of the three countries are still obedient to a head of government who comes from the prime offspring or 
offspring Uli Halawang. In the customary structures of the countries that joined it (such as the mass country) have their own customs. According to the customary elders that the arrival of the country's arrival is as follows:

a. The Wawane and Sanalu nations join the area where UliHalawang community is located. The arrival of Sanalu country to join the prime in the land of Hila accompanied by the surrender of a mosque bucket and a treaty to lift the religious penghulu (lebe) to fill the void in the mosque / Benoa

b. Massive Affairs in accordance with the agreement, they get a separate shelter from the land UliHalawang called UpuTelu

Separate places or borders of Uli Halawang and Upu Telu areas are pronounced with "Solo Hila Loto Lua" meaning that the country of Hila is divided in two, especially in the implementation of adat. In this place is built laid a monument made of the stone-shaped table on which placed shells or coolies bia. The moment as a symbol of the establishment of civilization, was in the place referred to the deliberation to start a customary work. The establishment of a monument in the land language called "Pile or Pale" (Pale or baileo) is owned also by Uli Halawang community. In the development both communities Uli Halawang and Upu Telu, each has a distinct character of the structure and custom structure, but in the behavior of social relations do not occur separation because the customary governance of the government given to the people of Hila as a whole.

\subsection{Elite Recruitment (King)}

\subsubsection{Mechanism and Selection process}

Process of the King's appointment in Hila land in its history experienced ups and downs. This is due to state intervention by issuing a number of policies that ultimately change the customary rules agreed upon. In accordance with the customary rules of the appointment of the king is carried out for generations and has no term limits. The king will be replaced if it has passed away, but this tenure changes when the enactment of Law of Number. 5 the year 1979 ( old law of village) concerning the village, not only the tenure but also affecting the structure and functions of other customary institutions. The process of selecting the current king is done by referring to Law of Number. 6 Year 2014, ( new law of village) the preparation process is done by the formation of the election committee, then the King invites the whole soa to inform that the election process will be carried out, this information is then continued by the head of soa by conducting meetings at the level of soa by presenting all the children soa to discuss candidates to be submitted in the election later. Soa level meetings are at the same time a means of identifying feasibility both with respect to governmental knowledge but more importantly as well as traditional and religious tenure.

As known Hila State has four big soa namely:

a. Tita, representing communion of Masappal or UpuTelu society (called soaUpuTelu)

b. Toto represents the community communityUliHalawang the first descendant of Totohatu (called SoaTomu)

c. Taapi, representing the community communityUliHalawang prime descendants Nusa TapiKapitanHitu (called SoaLating)

d. Pati, representing the community communityUliHalawang the prime descendant of

PatiTupa (called SoaOllong)

As previously explained customarily only two soa have the right as command soa, other meetings at other levels of soa, in addition to the candidate's worthiness at the same time at the 
soa level also discuss the vote support that will be given to candidates in the election later. ${ }^{1}$ Contestation in the election of the king as eligible as the election, each candidate campaigning both open and dialogue until the election process is done.

\subsubsection{King of Inauguration}

As the head of government who will carry out government duties, after the election, the king will be sworn in by the regent representing the district government. Swordsmanship and swearing are done in the sabua2, inauguration done by the head of the region is usually called the national inauguration. After the national inauguration is completed, the indigenous inauguration takes place in Baileo. The customary inauguration was done by Upu Hata. The indigenous inauguration process is marked by the crown prince's usage followed by taking the customary oath. In the process of inauguration done in two ways that are customary and national. The indigenous inauguration takes place first in Baileo / pale of indigenous custom made by three prime namely Nusa Tapi, Prime Totohatu (Tomu Nusa Huul) and prime Tomu Hitu Messeng. Inauguration process is also attended by all kings in the good peninsula Leihitu, Salahutu and West Leihitu. While the inauguration was formally done by the regent in the house of the elected king.

\subsection{The function of Customary Institution}

\subsubsection{King / Sultan}

Genealogical the right to occupy the position of head of government/king, given to soa parentah / command in this case Soa Taapi (Lating Nustapi) and Soa Pati Tupa (Ollong). The king in the adat structure carries out two functions other than as head of government, the King is also the customary head. As the head of government, the King performs the functions of government as mandated in the legislation of law (Law Number.6 Year 2014) on the authority based on the rights to origins and other authorities laid down in the law. The king emphatically carries out the functions of government, development, empowerment and social community. Whereas as the head of Adat, the King holds Adat functions, among others, responsible for the implementation of adat in the country, but also the king of socially responsible and judicial function (judge peace) in the country. In this dimension, the King is not only of heredity, but a king must also have a good knowledge of governmental knowledge, customary law, and religious qualities. The philosophy of King's power lies in three important functions:

1) The function of Protection: The king has a protective function especially protecting the customary order and its citizens from threats both physically and non physically because the community as a whole is a genealogy that from Negeri Hila

2) Peace Function: The function of the peacekeepers in addition to ensuring security and order in the neeri, the king must also be able to solve various problems that arise in the

${ }^{1}$ Interview with Mr. Sahabat Laisow. He is one of the indigenous leaders of Hila, who has experience in the implementation of customs. Mastery of customary governance is obtained from generation to generation and until now he is still entrusted to lead the customary procession in the field of governance, conflict resolution and cultural organization.

${ }^{2}$ Sabua, is a place to hold inauguration and take the oath. Sabua is usually done in front of the old house where the king's residence is chosen. After the inauguration proceeded with the entertainment event as the end of the process of the political constitution 
community whether it is related to social conflict between citizens, civil and criminal cases. Problem-solving puts the peace way that the ancestors of Hila have agreed upon. Although lately the way in some aspects does not solve the problem so that some people choose the formal path to solve the problem.

3) Sustainability Function: This function is run by the king to ensure that his people live safely and peacefully. At this level, the King is not always in the office but at certain times the King must conduct friendship between citizens.

\subsubsection{Ela Amang or Head Soa}

Ela amang is a place that structurally represents the community of several eyes of the house or knife tau which then joined and called soa. Implementation of custom functions that are in the soa in society UliHahalawang custom structures are handled by the head of soa as a representative of the house tau. One of the strategic roles of the soa chief is in addition to being the head of the soa chief at the same time as a member of the state's sanity (BPD) which carries out the articulation and aggregation functions of interests of both customary interests and interests related to government policy. The Head of Sao is chosen by deliberation by observing several criteria such as the age factor, the ability to build social relationships among children soa, etc. In addition to performing the aggregation function and articulation of the existence of soa as the most important community representatives is to carry out its functions as mandated in Law No. 6 of 2014 about the Village: Discussing and agreeing on the draft of village regulations with the village head, accommodating and channeling the aspirations of the village community and monitoring the performance of the village head. In this context, the existence of saniri members is very strategic, because it helps determine the future of Hila.

\subsubsection{Ela Ume Haha (Assistant King of the Field of Religion)}

Ela Ume Haha is an assistant king in the spiritual field who focuses on benoa ${ }^{3}$. The role of Ela Ume Haha is very strategic especially in the recruitment of positions, among others: the position of artisans, penghulu religion (lebe), and internal Ela Ume Haha own when there is a vacancy. Ela Ume Haha consists of representatives from some tau (marga) among others:

a. Tatisina with the title of Talauke

b. Kapitanhitu with the title Sine Wanepessy

c. Tomu with the title Uhe Tomu

d. Mahu with the title of Tuhe Mahu

e. Hakia with the title of Aki Hali

The process of appointment of strategic positions in the mosque is done in stages with the following mechanism:

- Uma Haha Ela deliberation with other positions

- The results of the deliberations are conveyed to the king/sultan to obtain approval for the adjustment of the position (at this stage no one has been nominated, this mechanism in the soil language is called "Pasa'aSoa" meaning giving up suggestions.

If the advice of Ela Ume Haha has called the name of the candidate and approved by the King, then the king's order that the proposed person be confirmed to occupy the position referred to. The King's inauguration order in the land language is called "SoaKa'a, SoaKulu" and

\footnotetext{
${ }^{3}$ Benoameans mosque. Benoa is the land language used by the ancestors, although the word mosque is present along with the entry of Islam spread by traders from Gujarat.
} 
subsequently submitted to UliHalawang and UpuTelu (community of Hila country in Benoa before preaching and Friday prayers) Ela Ume Haha performs the following functions:

1. Managerial functions: managerial functions, among others, regulate matters relating to the equipment mosque.

2. Coordination Function: Coordinate with other parties such as kings, upuhata, builders, related religious ritual activities.

3. Development Function: in addition to development in the form of addition, in addition to repairing a number of parts of the damaged mosque building.

4. Lebe Lifting Function (Penghulu Agama), Pengankatanlebe ${ }^{4}$ has done customarily, which begins with a ritual appearance of shadow in the mosque. This ritual is usually performed between 1 to 3 months. This activity is very sacred because the preparation of a person who will become a penghulu must get approval from all his ancestors either from the genealogy of his father and mother ${ }^{5}$. In addition to lifting the lebe Ela Ume Haha also lifted the builders who amounted to 12 people or in the language of land called tukanghusalua. Among others :

\subsubsection{Marga Function}

1) Ella / Ollong.(Great Tukang) Coordinate the implementation of the work, has the authority to determine the time of execution of work

2) Waling / Launuru Guides Provide consideration to the ella and Raja in decision-making related to the construction of the mosque.

3) TukangLating Plumber Reading Iirmeirjawi or kapata in traditional ceremonies

4) TukangTomu Delivering information related to meetings etc.

5) Ollong Handicrafts Provide consideration regarding the things that need to be improved on the construction of the mosque, then reported to Ella workers

6) Ulema Workers Provide consideration to Ella's engineers regarding things that need to be improved in the construction of the mosque

7) Uluelang Penguin Performs a supervisory function in order to implement the development in accordance with customary rules Carpenters

8) Lating Delivering decisions to the community regarding Development

9) TaneuAs a peacemaker

10) MahuMahuAs an architect in the construction, Tu Mahu has the right to put a plumb line

11) Assawala Toward Assist the hose in the execution of work

12) Selang.Hose holder of carpentry tools

Their respective roles and responsibilities must be coordinated through deliberation to carry out the physical work of the mosque and the overall work of the artist's decisions are conveyed to Elaa Ume Haha to be forwarded to the King / Sultan.

${ }^{4}$ Lebe is the language of the land pinned to the penghulu of Imam, Modim, Marbut, and Khatib. The lebes are usually appointed from the customary clan to occupy the position in the lebe (mosque). The penghulu usually taken from the descendants of men.

${ }^{5}$ Interview of former Ulema man. (alm). Muhammad Ulema. In the tradition of appointment of the lebe Ela Ume Haha must be patient because the process of appointment of the lebe must be prepared carefully. Because those who will be appointed at first have not been so deep in science lebe so it needs to be prepared right by the man. In another aspect the title of the lebe that is carried will end if the person resigns, does something disgraceful or dies. 


\subsection{Natural Resources Management}

\subsubsection{Sasi}

The natural resource management aspect is one of the most important dimensions. Natural resource regulation aims to ensure the sustainability of resources, both onshore and coastal. Public Communities in Peninsula Leihitu, has a tradition of managing natural resources that lasted for generations and maintained until now. Tradition sasi for example is believed to be one way not only to guarantee optimal results but at the same time can arrange fruit season regularly. Some advantages that can be obtained from the sasi:

\subsubsection{Source of Negeri Revenue}

In addition to getting a source of income from the Village Fund, Village Fund Allocation and other sources of income, sasi is also one way to earn revenue. Plant contract mechanisms such as nutmeg and coconut in the area, price and timeframe agreed between the holder of the sasi with the state government as well as traditional institutions such as mosques and churches ${ }^{6}$ will certainly contribute significant revenue. Average income earned from the management of Rp. 20 to 30 million for one season sasi ${ }^{7}$. For the holder of the sasi, the benefits to be gained are also very satisfactory if the taxes given by farmers in accordance with the rules of sasi. ${ }^{8}$

\subsubsection{Trust between Government and Society}

The community strongly believes its forest products to the government through the national authority ${ }^{9}$, the threat of theft is one of the most disturbing threats. With intensive control of the trustworthy the crops will be well preserved. Forest area and the number of personnel of authority determine the safety of the results. Similarly, the community will not believe in the government, if the expected forest product is not optimal due to weak supervision.

${ }^{6}$ Although the management of the sasi as a whole is managed by the government of the country, but in the division there is also a sasi on behalf of mosque and church, where the crop is divided for instance for nutmeg plants for the country, while coconut for church or vice versa.

7 The contract of sasi shall be conducted subject to the customary rules issued by the state. Vulnerable time of contract is usually 2 to 3 years for a single period. Opening until closing sasi depends on the rules of the household saniri. The arrangement of the sasi is very liquid because at the same time there are plants whose harvest time before sasi is opened, the bias of the crop owners to be harvested must apply for harvest permission to the government of the country.

${ }^{8}$ Customs granting mechanism in accordance with custom rules that have been determined for example when harvesting nutmeg and coconut for 1000 seeds of coconut / coconut is subject to excise duty 100 buji and delivered directly to the holder of sasi.Untuksasi held by the state government and religious institutions, excise submitted to the represented village government by one of the state government apparatus.

${ }^{9}$ Kewang is formed by the government of the country whose job is to control over the cultivated paste. Control is done in accordance with the schedule that has been made by the government of the country. Kewang is paid by the government of the country. 


\subsubsection{Collective Discipline.}

Sasi also teaches a collective discipline between the government and its people. Obeying the rules of sasi is very important. If there are individuals or groups of people who deliberately violate the rules that have been agreed upon then will be subject to sanctions. This sanction aims to provide a deterrent effect to the community not to do things - things that are prohibited when sasi is in progress.

\subsection{Process and Sasi Mechanism}

Sasi usually takes place from government initiatives or suggestions from the community, which feel important because of rampant theft or uneven harvest. If the government initiative of the country, then at the same time the government the country will invite the whole community to the country meeting in discussing the tender mechanism to the public for those interested in holding sasi, as well as the limit of land that has been decided by the country. As in the tender process conducted by explaining to the public land area as well as the highest set price standards. After that, the state government offers to the public. After the agreement between the holder of the sasi and the government then complete the administration and set the time sasi begins.

\subsubsection{Supervision Sasi}

In order for sasi to run well, need effective supervision. The government formed to form forest police or in the customary language known as kewang. Kewang performs its task of controlling the forest according to the specified schedule. Control/supervision to avoid theft but also to know the planting of nutmeg ready to harvest before the opening time begins. If there is a crop of nutmegs to harvested first, it will inform the owner to immediately reap the harvest. However, if the owner who knows the plants will harvested first then the owner contacted the kewang to punch directly the harvested crops. Once it confirmed the number of crops harvested, the owner contacts the local government to issue a harvest permit. Harvest permits issued are usually very limited between 1 to 3 days. Unlike the permit as the opening sasi which lasted less than two weeks.

\subsubsection{Sanction}

Before the sanctions apply, the proceedings of the perpetrators by presenting the authorities and witnesses. If proven guiltily concerned given the choice of sanctions in the form of fines, social and criminal sanctions. Fines depend on the number of stolen staple products, such as nutmeg, 1 piece of nutmeg stolen by a fine of Rp 10,000. /fruit. If not able, then the relevant social sanctions imposed paraded around the country while chanting errors committed. Social Sanctions is usually done at night. If not willing/able then the concerned handed over to the police for follow-up with the formal law (KUHP)

\subsubsection{Community Social Management}

Environmental safety and order is one of the most important aspects. The meaning of environmental security is none other than an effort to protect the public from acts of violence, theft, gambling and alcoholic beverages and illegal drugs. As a preventive measure, the government formed a team of youth leaders as an important part in supervising community members and groups who want to take actions that damage the environment, especially the social environment. In practice, in case of violation, members of the community or groups 
submitted to the government for trial. The government always puts forward custom sanctions rather formal sanctions, the argument because the offender is none other than the citizens who are likely also close family relationships so it is very embarrassing if his brother is given criminal sanctions

Customary sanctions are running around the country while shouting errors committed and invite people not to do the same. The deterrent effect of the sanctions is not expected to happen again in the future. Customary sanctions for all citizens of the country as well as those from abroad Hila. This moral verdict is very firm and usually done during the day. Like violation of liquor both the perpetrator and the seller the same sanctions. Social Section is one form of the sanction given to the members of the community which resulted in the violation. In addition to social sanctions, the previous state government with the community has agreed to other sanctions in the form of criminal sanctions if social sanctions are not accepted by the perpetrators. Criminal sanctions will also be imposed on the perpetrators if the person has escaped or ignored the call from the country.

\subsubsection{Conflict Management}

The people of Hila and jazeraleihitu countries have adopted a tradition of conflict resolution from their ancestors until now still preserved, although in some countries tradition of conflict resolution is becoming extinct. The tradition of conflict resolution is less attention because it influenced by a number of factors, among others:

1. The lack of socialization of indigenous figures related to the culture, this needs a concern for the future, especially for customary traditional leaders because socialization at the same time is the process of transfer of understanding to the new generation of children of the country so even though it takes place orally but can knowledge for next generation.

2. Unavailability of written documents inherited by the ancestors. In fact, almost certainly no single document that until now can read or stored either in old homes or by traditional leaders. Oral tradition is still one of the important instruments in narrating history.

3. Changes in the understanding function of the soil from the beginning actually the land is not only meant as a space to plant crops that serve for survival but at the same time actually the land also has a philosophical meaning is to unite the bones that spread. But now a function of the soil has distorted, the function of the soil than more on the orientation of the material because of the impetus needs and limitations of living space. The land became one of the most effective instruments of transactions to gain resources both money and services. In this dimension kinship values based on genealogy become neglected. The impact of the genealogy relation be tenuous, and even in a certain dimension gave birth to internal family conflict. Conflict resolution puts forward formal institutions such as courts or police and ignores customary institutions.

The process of settling land disputes customarily owned by the people of Hila country in its history once had a very sacred settlement model, which the parties to the dispute will present in one of the forums attended by traditional leaders, religion and those who disputed. This settlement tradition has buried the presence of state settlement through formal mechanisms. Although extinct, the tradition of conflict resolution in Hila State still continues to use customary tradition in accordance with the function of village government (king). which not only organizes its government function but also performs customary functions as a reconciliation judge. In carrying out the function, if there is a land dispute then the king invites the parties to the dispute, in the settlement process, all parties are given opportunity to convey the reasons and proof of ownership. In addition, witnesses from each party are given 
opportunity to present their testimony. After listening to the witnesses the king then made decision about the ownership rights of the disputed object. For those who disagree with the King's decision, please forwarded to the formal dispensation mechanism.

\subsubsection{Renovation of Traditional House}

As a country that has a customary tradition that is still and well maintained, preservation of the customary order either in the form of physical buildings such as old and nonphysical buildings in the form of dance ${ }^{10}$, land chanting, ${ }^{11}$ marriage procession and a sense of togetherness when one of the citizens who experienced the disaster. As is known in the land of Hila there is some tau house that has an old house as a gathering place for a large family of the house tau ${ }^{12}$. Existence of tau house in indigenous people of Hila is very important because as well as gathering place for all the big families at a certain customary moment, the old house is also a place to solve various problems before the problem reaches the party above (government and police). In order to keep the custom-house well maintained, renovation activities or house responsibility of the children's grandchildren family home tau. Tau house renovation activities usually begin with the renovation committee, then the committee works to prepare all renovation activities from the beginning until the renovation is complete. Every stage of renovation is always accompanied by traditional rituals both dance and singing.

This renovation activity also presents local government officials both district and province. Aspects of traditional house renovation philosophy is not only on the physical aspects of the old house renovation but the most important thing is to strengthen the relationship between children and grandchildren both genealogical relationship from the mother or father. In this dimension, it can see that renovation of traditional hose house is not only owned by the family only but owned by all the children of the grandchildren of the country, because of the blood relation relationship that almost covers all the people in Hila State. In addition to the old house Selang, within the last seven years, the people of Hila country managed to renovate a number of tau houses, among others: Pelatimu Old House, Mahu Old House, Old House LatingNustafi and Hatala Old House.

\subsubsection{Maatenu (Cakalele Dance)}

Cakalele dance is one of the traditional dances owned by the country on the island of Ambon and Maluku in general. The cakalele dance in the land language is known as maatenu. Cakalele dance is one of the dances that are often performed at indigenous traditional ceremony in the country, for example, the event of the king's inauguration or renovation of the house, maatenu dance is also staged reception of the guests who make a working visit to the Land of Hila. For reception of the guests maatenu dance is only done by soa Totohatu ie clan

${ }^{10}$ Maatenu(cakalele) is usually done on customary way. Maatenu is only done by the clan which is customary to have the Authority. Two genera are given the Authority to maatenu namely sopaliu and Elly (Tomunusahuul). Similarly, who the authority to beat and blow the coolie bia (snail) in cakalele dance namely Launuruelai

${ }^{11}$ Song song: is an original song that comes from an ancestor sung in the native language. In the land of hila there are a number of singing and dancing which until today still on guard well, both dance and nyayian only done at certain event. The singing of SairereHituo and Manu distance are two examples of Hila's ancestral singing

${ }^{12}$ Rumah Tau is another name of the clan or clan. MargaLating such as: is a label that carried by personal lineage from the party of Father (male) 
ely, mony and tomu and soa uku telu represented the clan of the house tau sopaliu (kapitan malesi). While in the traditional event such inauguration of the king, renovation of customhouse maatenu involving all the grandchildren of the country hila. ${ }^{13}$

Maatenu begins with preparing all the equipment in the form of clothes, machetes and salawaku whose activities concentrated in both old houses. Before maatenu begins the traditional elders give directions and beg the prayer of Allah SWT and the ancestors approval to maatenu can run well. In addition to the people performing the maatenu dance, one of the most important parts of the maatenu dance is the carrier tifa and the blower (tahuli) ${ }^{14}$. In the customary structure, the tau house that the authority to hit the drums and blow the school is the Launuru Elai clan. This done for generations. Before the maatenu event begins, as usual, the children and grandchildren Launuru Elai does the previous exercise with guidance of indigenous parents, this is too unsure that during the implementation will not happen errors errors that can cut the value maatenu. Before the maatenu event starts all the people on duty hit the tifa or blow first collected in Launuru old house to the preparation as well as request approval from the ancestors to the process maatenu can run well. Next the entourage to the house tau to pick up people who will do maatenu and then do with maatenu to activities or events customary held.

\section{Conclusion}

Portrait of democracy in the election process of the State élite (Raja) directly, based on local culture that is highly respected and appreciated. Procedural mechanisms based on formal rules, but still putting cultural-based requirements into a very important part because with the cultural norms, honesty, justice, togetherness and brotherhood become the basic capital in guarding the democratic process that ultimately the leading élite (Raja) the selected ones have a proven capacity, especially the understanding of adat, culture, religion and leadership as guidance in managing power.

Natural resource management that promotes local culture, has a positive impact on the sustainability and quality of the results. The substantive local value of the management model is to make sure the presence of collective discipline against commonly agreed rules. High confidence in the government apparatus of the country as the executor and the certainty of production of agricultural products evenly, and protection of good Resources

The ensuring of security and order in society is very important. Existence of sanctions based on strong and clear local culture against the violators provides positive learning to other citizens more wise in action. Prioritizing geological relations, settlement of violations puts forward the choice of cultural settlement without overriding formal legal aspects. Formal law do when cultural settlement does not find common ground.

\footnotetext{
${ }^{13}$ Interview with Mr. Zulkarnaen Ely One of the successors of maatenu dance from ely descent (tomunusahuul). Maatenu dance according to him needs to maintained because it is one of the most important asset especially related to the cultural sustainability of the people of Hila country. Maatenu also teaches togetherness, unity and obedience to leaders.

${ }^{14}$ Tahuliis another name of a large shellfish and when blown it will produce a loud enough sound. The thrill of the sound believed to cause the effect of magic accompanied by possessed by the maatenu and people who have strong traditional relationships. This will take place until there is a customary figure who stops the possession.
} 
Resolving conflicts by promoting cultural aspects, placing the path of peace as the settlement mechanism. As a judge, the king plays an important role in resolving the problem but if the conflicting party feels aggrieved, it is welcome to take legal action.

Cultural preservation realized with the maintenance of cultural assets in the form of old houses and art. Renovation of traditional houses has meaning as a medium to strengthen kinship ties in genealogical and fraternal relationships for the society.

\section{References}

[1] B. Suryaningrat, Pemerintahan Administrasi Desa Dan Kelurahan. Jakarta: Aksara Baru, 1985.

[2] S. Kartohadikoesoemo, Desa. Bandung: Penerbit Sumur, 1965.

[3] D. . Burger, Structuurvveranderinge in de Javaanesen samenieving, Indonesia. N.V.Ugeveverij W.Van Hoeves: Gravanhego, 1949.

[4] C. Lay, "Pilkada langsung dan pendalaman demokrasi," J. Ilmu Sos. dan Ilmu Polit., vol. 11, no. 1, pp. 63-92, 2007.

[5] H. Nawawi, Metode Penelitian Bidang Sosial. Yogjakarta: Gadjah Mada University Press, 2005.

[6] S. Hadi, Metodologi Research. Yogyakarta: Fakultas Psikologi, UGM, 1986.

[7] M. Nasution, Metode Penelitian Naturalistik, 1st ed. Tarsito Bandung, 1992.

[8] L. J. Moleong, Metodologi Penelitian Kualitatif. Bandung: Remaja Rosda Karya.

[9] Suyatno, Menjelajah Demokrasi. Yogyakarta: Liebe Book, 2004.

[10] R. A. Dahl, Perihal Demokrasi Menjelajahi Teori dan Praktik Demokrasi secara singkat. Jakarta: Yayasan Obor Indonesia, 2001.

[11] R. A. Dahl, Dilema Demokrasi Pluralis. Jakarta: Radar Jaya Offset, 1985.

[12] A. Watloly, "Beberapa Sketrsa pemikiran Filosofis Dalam membangun Regulasi Kearifan Lokal Di Kancah Merebaknya Rasionalitas Modern.” Yogyakarta, 2006.

[13] J. Riwokaho and C. Lay, Demokrasi Lokal. Yogyakarta: Program Pasca Sarjana UGM Yogyakarta, 2010. 